\title{
Pengaruh Pemberian Ekstrak Etanol Daun Kemangi (Ocimum basilicum L.) terhadap Cedera Hepatosit : Kajian pada Bahan Biologis Tersimpan (BBT) Hepar Mencit (Mus musculus) Jantan Galur Swiss yang Diinduksi Asam Urat
}

\author{
Effects of Ethanol Extract of Basil Leaves (Ocimum basilicum L.) on Hepatocyte Injury: Study on
} Stored Biological Materials (BBT) of Liver Mice (Mus musculus) Swiss male strain induced by gout

\author{
Aprili Wulandari $^{1 *}$, Andi Muh. Maulana ${ }^{1}$, Rizka Adi Nugraha Putra', Muhammad Fadhol Romdhoni ${ }^{1}$ \\ ${ }^{1}$ Fakultas Kedokteran, Universitas Muhammadiyah Purwokerto \\ *Penulis koresponesi: Aprili Wulandari. Email: aprili644@gmail.com
}

\begin{abstract}
ABSTRAK
Latar Belakang: Kadar asam urat yang tinggi dalam darah disebut dengan kondisi hiperurisemia. Hiperurisemia diketahui dapat menyebabkan terbentuknya radikal bebas sehingga terjadi stress oksidatif dan mengakibatkan kerusakan hepatosit. Daun kemangi (Ocimum basilicum) diketahui memiliki kandungan antioksidan dan sifat hepatoprotektif yang dapat digunakan untuk terapi pencegahan kerusakan hepar akibat hiperurisemia.

Metode: Penelitian ini merupakan penelitian experimental dengan post-test only controlled group design. Penelitian ini menggunakan sampel bahan biologi tersimpan dalam bentuk organ hepar mencit (Mus musculus) jantan galur swiss yang terbagi menjadi 4 kelompok perlakuan. Analisis data menggunakan uji statistik ANOVA dan perhitungan jumlah hepatosit mencit menggunakan aplikasi Image-J.

Hasil: Terdapat perbedaan yang bermakna pada kelompok kontrol positif terhadap kelompok perlakuan 1 (KP1) $(\mathrm{p}=0,035)$, kelompok kontrol positif terhadap kelompok perlakuan 2 (KP2) $(\mathrm{p}=0,000)$, dan kelompok kontrol positif terhadap kelompok perlakuan 3 (KP3) (p=0,000).

Kesimpulan: Pemberian ekstrak etanol daun kemangi (Ocimum basilicum) dapat menurunkan kerusakan hepatosit pada mencit yang diinduksi asam urat.
\end{abstract}

Kata kunci: ocimum basilicum, hepatosit, mus musculus.

\begin{abstract}
Background: A high level of uric acid in the blood was called hyperuricemia. Hyperuricemia was known as the cause of the formation of free radicals that resulted in oxidative stress and hepatocyte damage. It was known that basil (Ocimum basilicum) leaves had antioxidant content and hepatoprotective properties which could be used to prevent liver damage due to hyperuricemia.

Method: It was experimental study with post-test only controlled group design. Stored biological material samples in the form of liver organs of mice (Mus musculus) Swiss webster were used in this study which were divided into 4 treatment groups. The data were analyzed by using ANOVA statistical test. The Image-J application was used to calculate the number of hepatocytes of mice.

Results: There were significant differences in the positive control group towards the first treatment group $($ KP1) $(p=$ $0.035)$, positive control group towards the second treatment group $(K P 2)(p=0.000)$, and positive control group towards the third treatment group $(K P 3)(p=0.000)$.

Conclusion: The effect of ethanol extract of basil (Ocimum basilicum) leaves can reduce hepatocyte damage on mice which were induced by uric acid.
\end{abstract}

Keywords: ocimum basilicum, hepatocytes, mus musculus. 


\section{PENDAHULUAN}

Asam urat merupakan hasil metabolisme akhir dari purin yang merupakan salah satu bentuk komponen asam nukleat yang terdapat dalam inti sel tubuh manusia. Sedangkan, purin itu sendiri ialah turunan dari protein yang terkandung di dalam tubuh. ${ }^{1}$ Nilai normal asam urat pada pria usia $\geq 15$ tahun yaitu $6-8,5$ $\mathrm{mg} / \mathrm{dL}$ sedangkan pada wanita usia $\geq 18$ tahun yaitu 2,3 - 6,6 mg/dL. Kadar asam urat yang tinggi dalam darah dapat disebut dengan kondisi hiperurisemia. $^{2}$

Hiperurisemia merupakan salah satu faktor resiko terjadinya penyakit pirai. Penyakit pirai (gout) merupakan serangan berulang arthritis akut ditandai dengan adanya penumpukan monosodium urat dalam jaringan. $^{3} \quad$ Prevalensi hiperurisemia di Amerika Serikat didapatkan sebesar 21,4\%.4 Di Indonesia, prevalensi penyakit gout sendiri diperkirakan 1,6-13,6/100.000 orang dan prevalensi ini meningkat sesuai dengan bertambahnya usia. Di Indonesia, asam urat berada pada urutan kedua setelah osteoartritis. ${ }^{5}$ Pada penelitian di Kabupaten Banyumas, Jawa Tengah prevalensi hiperurisemia sebesar $21,15 \% .^{6}$

Hiperurisemia juga merupakan salah satu penyebab terjadinya cedera hepatosit, karena asam urat dihasilkan dalam keadaan proses penghancuran nukleotida yang tergolong dalam Demage-Associated Molecular Patterns (DAMP) yang dilepaskan oleh sel hepatosit yang mati sehingga menambah risiko terjadinya inflamasi pada jaringan hepar. $^{7}$ Kondisi hiperurisemia juga dapat menyebabkan terbentuknya radikal bebas yang dapat menyebabkan stress oksidatif dan mengakibatkan kerusakan sel hepatosit. ${ }^{8}$

Radikal bebas ini dapat di netralisir oleh antioksidan. Antioksidan dapat berupa antioksidan endogen yang dapat dibentuk oleh tubuh sendiri, maupun antioksidan eksogen berupa suplemen dari luar tubuh berasal dari makanan, minuman, obat-obatan, dan lainlain. Antioksidan sangat mudah dioksidasi, sehingga radikal bebas akan mengoksidasi antioksidan dan melindungi molekul lain dalam sel dari kerusakan akibat oksidasi oleh radikal bebas atau oksigen reaktif. ${ }^{9}$

Salah satu sumber antioksidan yang mudah ditemukan dan sudah banyak digunakan untuk pengobatan tradisional di Indonesia berasal dari tumbuh-tumbuhan contohnya daun kemangi. Kandungan utama yang terdapat pada daun kemangi (Ocimum basilicum) yang bersifat sebagai antioksidatif adalah flavonoid. Senyawa tersebut dapat menghambat terbentuknya asam urat dengan aktivitasnya menghambat kerja enzim xanthine oksidase sehingga tidak terjadi penumpukan kristal urat. ${ }^{10}$

Sebuah uji preklinik pada kelompok mencit yang diberikan ekstrak etanol daun kemangi dosis $11,2 \mathrm{mg} / 20 \mathrm{gBB}, 14 \mathrm{mg} / 20 \mathrm{gBB}$ dan $16,8 \mathrm{mg} / 20 \mathrm{gBB}$ dengan pelarut etanol $96 \%$ yang diinjeksi asam urat selama 14 hari dapat mempengaruhi kadar ALT dan AST pada hepar. Kadar asam urat normal pada mencit adalah 0,5-1,4 mg/dl, dan mencit dikatakan mengalami hiperurisemia bila kadar asam uratnya $1,7-3,0 \mathrm{mg} / \mathrm{dl} .^{11}$

\section{BAHAN DAN METODE}

\section{Bahan}

Bahan yang digunakan dalam penelitian ini adalah air, alkohol 96\%, alkohol 80\%, alkohol asam $1 \%$, eousin, entelan, formalin $10 \%$, hematoksilin, paraffin, spesimen hepar mencit jantan galur swiss, xylol.

\section{Metode}

Penelitian ini merupakan jenis penelitian quasy experimental dengan rancangan penelitian post test only controlled group design yang dilakukan mulai bulan September 2018 sampai dengan Januari 2019. Penelitian ini dilakukan di Laboratorium Farmakologi Fakultas Kedokteran Universitas Muhammadiyah Purwokerto, Laboratorium Riset Fakultas Kedokteran Universitas Jenderal Soedirman dan Laboratorium Patologi Anatomi Rumah Sakit Umum Daerah Prof. DR. Margono Soekardjo Purwokerto. Sebelum dilakukan penelitian 
pengambilan hepar dari hewan coba (mencit) telah dilakukan pada Januari 2018. Organ telah difiksasi dengan larutan Buffered Neutral Formalin (BNF) $10 \%$ yang selanjutnya menjadi Bahan Biologi Tersimpan (BBT) dari Januari 2018 sampai Mei 2018 dan BBT telah diawetkan dalam bentuk blok paraffin.

Hewan percobaan dikelompokkan menjadi 4 (empat) kelompok, masing-masing terdiri dari 4 (empat) ekor hewan coba yang terdiri dari; kelompok kontrol positif $(\mathrm{K}+)$, kelompok perlakuan 1 (KP1), kelompok perlakuan 2, dan kelompok perlakuan 3. Kelompok kontrol positif $(\mathrm{K}+)$ diberi asam urat $125 \mathrm{mg} / \mathrm{kgBB}$, $\mathrm{KP} 1$ diberi asam urat $125 \mathrm{mg} / \mathrm{kgBB}$ dan setelah dua jam diberi ekstrak etanol daun kemangi 11,2 mg/20 gBB, KP2 diberi asam urat $125 \mathrm{mg} / \mathrm{kgBB}$ dan setelah dua jam diberi ekstrak etanol daun kemangi $14 \mathrm{mg} / 20 \mathrm{gBB}$, serta KP3 diberi asam urat $125 \mathrm{mg} / \mathrm{kgBB}$ dan setelah dua jam diberi ekstrak etanol daun kemangi 16,8 mg/20 gBB. Semua dilakukan secara intragastrika selama 14 hari. Jumlah sel hepatosit yang mengalami piknosis, karioreksis, dan kariolisis diamati dengan pembesaran 400 kali pada 5 lapang pandang di bawah mikroskop, yang kemudian dilakukan penghitungan skor kerusakan hepar.

\section{Pengumpulan Sampel}

Sampel/hewan coba yang digunakan adalah mencit (Mus musculus) jantan galur swiss dengan jumlah sebanyak 16 ekor, dengan masing-masing 4 ekor untuk setiap kelompok percobaan.

\section{Analisis Statistik}

Analisis sel hepatosit akan diuji satu-satu dan diolah dengan perangkat lunak pengolah statistik. Data yang diperoleh dianalisis menggunakan uji statistik. Uji normalitas data yang digunakan yaitu Shapiro-Wilk. Data terdistribusi normal, didapatkan p>0,05. Kemudian dilanjutkan dengan uji beda menggunakan uji statistik parametrik One-way ANOVA, dan apabila didapatkan perbedaan yang bermakna, maka dilakukan uji lanjut LSD (Least Significant Difference).

\section{HASIL \& PEMBAHASAN}

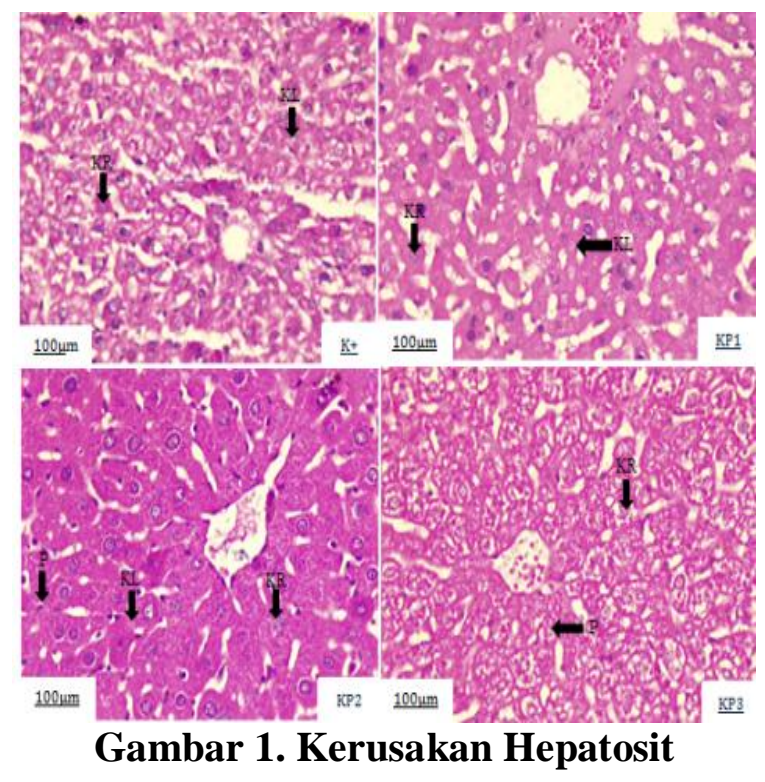


Keterangan :

$\mathrm{P}$ : inti piknosis ditandai dengan inti e-ISSN : 2657-2389

menyusut, padat, batas tidak teratur, hiperkromatik

KR: inti karioreksis ditandai dengan nukleus mengalami fragmentasi menjadi kecil dan tersebar.

KL: inti kariolisis ditandai dengan nukleus lisis, tidak adanya sel sehingga kehilangan kemampuan untuk diwarnai atau tampak pucat.

Data hasil penelitian yaitu jumlah inti sel hepatosit yang mengalami kerusakan (piknosis, karioreksis, dan kariolisis) yang dihitung dalam 5 lapang pandang, kemudian dihitung skornya menggunakan rumus skor kerusakan hepatosit. Kemudian data yang diperoleh dari 4 (empat) kelompok akan diuji normalitasnya menggunakan uji Shapiro-Wilk. Hasil uji normalitas kerusakan hepatosit dari masing-masing kelompok disajikan dalam Tabel 1 dibawah ini.

Tabel 1. Uji normalitas masing-masing perlakuan

\begin{tabular}{clcc}
\hline No & Kelompok & $\begin{array}{c}\text { Rerata sel } \\
\text { kerusakan } \\
\text { hepar }\end{array}$ & Nilai P \\
\hline 1 & K+ & $257,75 \pm 6,344$ & 0,991 \\
2 & KP1 & $240 \pm 3,266$ & 0,683 \\
3 & KP2 & $204 \pm 17,814$ & 0,175 \\
4 & KP3 & $169 \pm 8,869$ & 0,798 \\
\hline
\end{tabular}

Tabel 1 menunjukan rerata nilai perhitungan kerusakan hepatosit pada keempat kelompok hewan coba yaitu untuk kelompok kontrol, kelompok perlakuan dengan dosis $11,2 \mathrm{mg} / 20 \mathrm{gBB}$, dosis $14 \mathrm{mg} / 20 \mathrm{gBB}$ dan dosis $16,8 \mathrm{mg} / 20 \mathrm{gBB}$ (KP1, KP2 dan KP3) memberikan gambaran klinis ekstrak etanol daun kemangi menurunkan rerata sel kerusakan hepar. Kelompok kontrol positif $(\mathrm{K}+)$ memiliki nilai rata-rata skor kerusakan hepatosit paling tinggi yaitu 257,75. Kelompok perlakuan 1 (KP1) menujukan perbedaan rerata sel kerusakan hepar yang lebih besar dibandingkan kelompok perlakuan 2 (KP2). Kelompok perlakuan 3 (KP3) menunjukan rerata sel kerusakan hepar yang paling rendah dibandingkan kelompok perlakuan 1 (KP1) maupun kelompok perlakuan 2 (KP2) ) yaitu 169.

Data kerusakan hepatosit mencit (mus musculus) jantan galur swiss dianalisis menggunakan uji normalitas diperoleh nilai $p$ pada $\mathrm{K}+, \mathrm{KP} 1, \mathrm{KP} 2$ dan KP3 secara berturutturut yaitu $0,991,0,683,0,175$ dan 0,798 . Hasil nilai $p>0,05$ maka dapat diambil kesimpulan bahwa keempat kelompok berdistribusi normal. Setelah data menunjukkan terdistribusi normal kemudian dilanjutkan menggunakan uji Homogenity of Varience yang menunjukkan data bersifat homogen dengan nilai $\mathrm{p}=0,079$.

Gambar 2 memperlihatkan bahwa ekstrak etanol daun kemangi dapat mengurangi kerusakan hepatosit mencit (mus musculus) jantan galur swiss akibat pemberian asam urat. Kerusakan hepatosit terlihat semakin menurun pada perlakuan dengan pemberian ekstrak etanol daun kemangi. Hal ini terlihat pada garis grafik yang semakin menurun dimana tertinggi pada kelompok kontol positif $(\mathrm{K}+)$ dan terendah pada kelompok perlakuan 3 (KP3).

Data skor kerusakan hepatosit tiap kelompok selanjutnya dilakukan uji Anova untuk mengetahui perbedaan skor kerusakan hepatosit antara keempat kelompok yaitu kelompok K+, KPI, KP2 dan KP3. Hasil analisis uji ANOVA skor kerusakan hepatosit pada semua kelompok perlakuan didapatkan nilai $\mathrm{P}=0,000$ dimana nilai ini lebih kecil dari $0,05 \quad(\mathrm{P}<0,05)$ sehingga dapat disimpulkan 
bahwa terdapat perbedaan rata-rata skor kerusakan hepatosit yang bermakna antara kelompok K+, KP1, KP2 dan KP3.

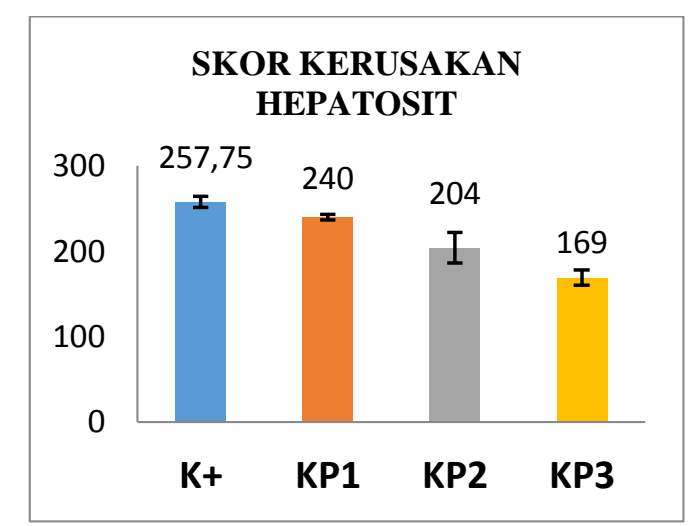

Gambar 2. Grafik rata-rata skor kerusakan hepatosit

Tabel 2. Hasil uji LSD antara keempat kelompok perlakuan

\begin{tabular}{|c|c|c|c|}
\hline \multicolumn{2}{|l|}{ Pasangan Kelompok } & Nilai $p$ & Kesimpulan \\
\hline \multirow{3}{*}{$\begin{array}{l}\text { Kelompok kontrol positif } \\
\qquad(\mathrm{K}+)\end{array}$} & KP1 & $0,035^{*}$ & Signifikan \\
\hline & KP2 & $0,000 * *$ & Signifikan \\
\hline & KP3 & $0,000 * *$ & Signifikan \\
\hline \multirow{2}{*}{$\begin{array}{c}\text { Kelompok perlakuan I } \\
(\mathrm{KP} 1)\end{array}$} & KP2 & $0,000 * *$ & Signifikan \\
\hline & KP3 & $0,000 * *$ & Signifikan \\
\hline $\begin{array}{c}\text { Kelompok perlakuan II } \\
\text { (KP2) }\end{array}$ & KP3 & $0,001 * *$ & Signifikan \\
\hline
\end{tabular}

Dari hasil tersebut didapatkan bahwa nilai p antar K+-KP1, K+-KP2, K+-KP3, KP1-KP2, KP1-KP3, KP2-KP3 adalah 0,000, lebih kecil dari nilai $\alpha=0,05$ menunjukan adanya perbedaan nyata pada setiap kelompok.

Pada penelitian ini ditemukan terjadinya kerusakan hepatosit pada seluruh kelompok percobaan dengan tingkat keparahan yang berbeda. Tingkat keparahan yang paling tinggi ditemukan pada kelompok kontrol positif $(\mathrm{K}+)$ yang hanya mendapatkan perlakuan berupa pemberian asam urat $125 \mathrm{mg} / \mathrm{kgBB}$. Kerusakan sel hepar dapat berupa kerusakan ringan pada sel hepar, dalam bentuk perubahan perlemakan sampai nekrosis hepatik yang masif. Sel yang mengalami nekrosis ukuran selnya biasanya membesar, sering tidak bisa mempertahankan integritas membrannya, komponen dalam sel tersebut mengalami penghancuran. Umumnya perubahan-perubahan lisis yang terjadi pada sel nekrotik dapat terjadi pada semua bagian sel, tetapi perubahan pada inti sel adalah petunjuk paling jelas pada kematian sel.

Kerusakan hepatosit dapat terjadi karena akumulasi asam urat dalam tubuh yang menyebabkan kadar purin dalam tubuh meningkat. Purin dalam tubuh dapat diubah menjadi asam urat endogen oleh enzim santin oksidase di dalam darah. Enzim xantin oksidase tersebut juga mampu mengubah hipokxantin menjadi xantin dan xantin 
menjadi asam urat. $^{14}$ Mekanisme ini menyebabkan tingginya kadar asam urat dalam darah dan tidak dapat dieksresikan secara maksimal. Flavonoid mampu menurunkan kadar asam urat dengan cara menghambat aktivitas enzim xantin oksidase, karena flavonoid dianggap sebagai inhibitor yang baik untuk XO juga memiliki aksi antioksidan. ${ }^{15}$

Dari uji ANOVA didapatkan perbedaan rata-rata skor kerusakan hepatosit yang bermakna antara kelompok K+, KPI, KP2 dan KP3. Hasil uji LSD menunjukan perbedaan yang nyata antara kelompok kontrol positif $(\mathrm{K}+)$ dengan kelompok perlakuan 1 (KP1) dan menunjukkan perbedaan sangat nyata pada kelompok kontrol positif $(\mathrm{K}+)$ dengan kelompok perlakuan 2 (KP2), kelompok kontrol positif $(\mathrm{K}+)$ dengan kelompok perlakuan 3 (KP3), kelompok perlakuan 1 (KP1) dengan kelompok perlakuan 2 (KP2), kelompok perlakuan 1 (KP1) dengan kelompok perlakuan 3 (KP3), kelompok perlakuan 2 (KP2) dengan kelompok perlakuan 3 (KP3). Berdasarkan hasil tersebut maka dapat disimpulkan bahwa ekstrak etanol daun kemangi dapat berfungsi menurunkan kerusakan sel hepatosit. Hasil tersebut sesuai dengan penelitian yang dilakukan oleh Ahmed, et al., (2015).

\section{KESIMPULAN}

Pemberian ekstrak etanol daun kemangi (Ocimum basilicum L.) dapat mencegah cedera hepatosit secara bermakna pada hepat mencit (Mus musculus) jantan galur Swiss yang diinduksi asam urat. Peningkatan dosis ekstrak etanol daun kemangi (Ocimum basilicum L.) dari $11,2 \mathrm{mg} / 20 \mathrm{gBB}, 14 \mathrm{mg} / 20$ $\mathrm{gBB}$, menjadi 16,8 $\mathrm{mg} / 20 \mathrm{gBB}$ dapat meningkatkan proteksi terhadap cedera hepatosit mencit (Mus musculus) jantan galur Swiss yang diinduksi asam urat.

\section{UCAPAN TERIMAKASIH}

\begin{tabular}{lrr}
\multicolumn{2}{c}{ Saya ucapkan terimakasih kepada } \\
Fakultas & Kedokteran & Universitass \\
Muhammadiyah Purwokerto yang telah
\end{tabular}

mendukung pembuatan artikel ini dan menyediakan fasilitas Laboratorium sampai penelitian ini selesai. Kepada petugas laboran Laboratorium Farmakologi Fakultas Kedokteran Universitas Muhammadiyah Purwokerto dan Laboratorium Riset Fakultas Kedokteran Universitas Jenderal Soedirman yang telah membantu menyelesaikan penelitian ini.

\section{DAFTAR PUSTAKA}

1. Mantiri INR, Rambert GI, Wowor MF. Gambaran kadar asam urat pada pasien penyakit ginjal kronik stadium 5 yang belum menjalani hemodialisis. Jurnal $e$ Biomedik (eBm). 2017;5(2).

2. KEMENKES RI. Pedoman interpretasi data klinik. 2011.pp.52-56. Available From: URL Hiperlink: https:// fdokumen.com/document/pedomaninterpretasi-data-klinik kemenkes2011.html

3. BPOM. Dokumentasi ramuan etmomedisin obat asli indonesia. 2013

4. You L, Liu A, Wuyun G, Wu H, Wang P. Prevalence of hyperuricemia and the relationship between serum uric acid and metabolic syndrome in the asian mongolian area. Journal of Atherosclerosis and Thrombosis. 2014;21(4):355-365.

5. Sukarmin. Faktor-faktor yang berhubungan dengan kadar asam urat dalam darah pasien gout di desa kedungwinong sukolili pati. The $2^{\text {nd }}$ University Research Coloquium. 2015. Semarang: STIKES Muhammadiyah Kudus. Semarang: LPPM UNIMUS;2015.

6. Indahsari KN. histopatologi hepar tikus putih (rattus novergicus ) yang diinduksi dengan parasetamol dosis toksik pasca pemberian ekstrak etanol daun kelor (moringa oleifera). Kimia Riset. 2017:2(2):123-130.

7. Ives A, Nomura J, Martinon F, Roger T, LeRoy D, Miner JN, et al. Xanthine oxidoreductase regulates macrophage il1 $\beta$ secretion upon nlrp3 inflammasome 
activation. Nature Communications. 2015; 6555.

8. Dianati NA. Gout and hyperuricemia. $J$ Majority. 2015;82-89.

9. Werdhasari A. Peran antioksidan bagi kesehatan. Jurnal Biomedik Medisiana Indonesia. 2014;1(2):59-68.

10. Anggun, Ismanto AY, Masi G. Pengaruh air rebusan daun kemangi terhadap kadar asam urat darah pada penderita hiperurisemia di wilayah kerja puskesmas wolaang. Jurnal Keprawatan (eKp). 2016;4(1):1-7.

11. Adam AK, Kusumawati A, Putra RAN. Pengaruh pemberian ekstrak etanol daun kemangi sayur (ocimum basilicum) terhadap kadar serum alanin aminotrasferase (alt) dan aspartat aminotrasferase (ast) mencit (mus musculus) jantan galur swiss yang diinjeksi asam urat. 2018;1(2):1-7.

12. Dahlan MS. Besar sampel dan cara pengambilan sampel. $3^{\text {rd }}$ edn. Jakarta: Salemba Medika. 2010

13. Ahmed BA, Mohamed AH, Ali SA, Abuelgasim AI. Hepatoprotective activity of ethanol extract of ocimmum basillicum against ccl4-induced hepatotoxicity in albino rats. Journal of Natural and Medical Sciences (JNMS). 2015;16(2):1118.

14. Saigal, Agrawal JR, Huebner J, Hedgecock J, Sehgal AR, Jung P, Simon SR. Medical students' knowledge of the US health care system and their preferences for curricular change: a national survey. Academic Medicine. 2015;80(5):484-488.

15. Al-Azzawie, Hasan F, Samah A. Abd. Effect of some plant extracts on serum uric acid levels, and xanthine oxidase activity in vitro and in oxonate-induced hyperuricemic rats. European Journal of Pharmaceutical and Medical Research. 2015;2(6):55-61. 